\title{
Modelling the interaction of structural and synaptic plasticity
}

\author{
Michael Fauth ${ }^{1,2^{*}}$, Christian Tetzlaff ${ }^{1,2}$, Florentin Wörgötter ${ }^{1,2}$ \\ From Twenty Second Annual Computational Neuroscience Meeting: CNS*2013 \\ Paris, France. 13-18 July 2013
}

Recent experiments show that learning is associated with structural changes in neural tissue $[1,2]$. The underlying mechanism, named structural plasticity, drives the formation of new synapses and the removal of existing ones on a timescale of days to weeks. This enlarges the potential for information storage in neuronal networks [3] and is, thus, important for understanding long-term memory formation. On shorter timescales (minutes to hours) another process - synaptic plasticity - influences the transmission efficiency (weights) of a synapse and, therefore, also contributes to information storage.

We investigate the interaction between these two processes - still widely unknown - in the following rather simple model: We use rate based neurons with the total transmission efficiency between two neurons being just the sum of weights of all synapses connecting these two neurons. Thus, the number of synapses as well as their weights influence the same quantity and we can investigate the effects arising from structural and synaptic plasticity competing on different timescales. Synaptic plasticity is modeled by Hebbian learning with weight-dependent synaptic scaling [4]. For structural plasticity we have to assume a certain number of potential synaptic sites. The formation of a synapse at each of these potential synaptic sites happens at random with a fixed formation probability. The removal of existing synapses also happens randomly, but with a probability, which depends on weight and postsynaptic activity.

Although the interaction of these processes is quite complex, we show that the system converges to a stable state. In this state the activity determines the probability distribution of number and strength of synapses between

\footnotetext{
* Correspondence: mfauth@physik3.gwdg.de

'Drittes Physikalisches Institut, Georg-Auguist Univeristät Göttingen, 37077, Germany
}

Full list of author information is available at the end of the article neurons. This interplay could also serve to form highly interconnected clusters, which are candidates for memory representation (cell assemblies).

\section{Author details}

'Drittes Physikalisches Institut, Georg-Auguist Univeristät Göttingen, 37077, Germany. ${ }^{2}$ Bernstein Center for Computational Neuroscience Göttingen, Germany.

\section{Published: 8 July 2013}

\section{References}

1. Xu T, Yu X, Perlik AJ, Tobin WF, Zweig JA, Tennant K, Jones T, Zuo J: Rapid formation and selective stabilization of synapses for enduring motor memories. Nature 2009, 462:915-919.

2. Yang G, Pan F, Gan W-B: Stably maintained dendritic spines are associated with lifelong memories. Nature 2009, 462:920-924.

3. Chklovskii DB, Mel B, Swoboda K: Cortical rewiring and information storage. Nature 2004, 431:782-788.

4. Tetzlaff C, Kolodziejski C, Timme M, Wörgötter F: Synaptic Scaling in Combination with many Generic Plasticity Mechanisms Stabilizes Circuit Connectivity. Front Comput Neurosci 2011, 5:47.

doi:10.1186/1471-2202-14-S1-P416

Cite this article as: Fauth et al:: Modelling the interaction of structural and synaptic plasticity. BMC Neuroscience 2013 14(Suppl 1):P416.
Submit your next manuscript to BioMed Central and take full advantage of:

- Convenient online submission

- Thorough peer review

- No space constraints or color figure charges

- Immediate publication on acceptance

- Inclusion in PubMed, CAS, Scopus and Google Scholar

- Research which is freely available for redistribution

Submit your manuscript at www.biomedcentral.com/submit
( Biomed Central
C Biomed Central

(C) 2013 Fauth et al; licensee BioMed Central Ltd. This is an Open Access article distributed under the terms of the Creative Commons Attribution License (http://creativecommons.org/licenses/by/2.0), which permits unrestricted use, distribution, and reproduction in any medium, provided the original work is properly cited. 